\title{
Molecular confirmation of Nothopassalora personata causing leaf spot of peanut in Iran
}

\author{
Mounes Bakhshi ${ }^{1}$ (1) $\cdot$ Rasoul Zare $^{1}$ (i) \\ Received: 8 October 2019 / Accepted: 6 February 2020 / Published online: 11 February 2020 \\ (C) Australasian Plant Pathology Society Inc. 2020
}

\begin{abstract}
Morphological and molecular studies confirmed Nothopassalora personata as the cercosporoid fungus causing leaf spot of peanut (Arachis hypogaea) in Iran. This is the first molecular evidence of $N$. personata in Iran (Asia), although it was previously reported as Passalora personata, Cercospora personata or Cercosporidium personatum based on morphological examinations. Molecular identification was done using sequence data of LSU, ITS and rpb2 loci of closely related taxa in the Bayesian analysis. Furthermore, parts of the actA, tefl, cmdA and his 3 loci were sequenced for the first time for this species.
\end{abstract}

Keywords Cercosporoid $\cdot$ Mycoshaerellaceae $\cdot$ Phylogeny $\cdot$ Passalora

Peanut or groundnut (Arachis hypogaea) is one of the oil seed crops where its seeds are used for direct human consumption and as an oil and protein source (Kadidia et al. 2018). Among fungal diseases of peanut, leaf spot is important disease of this plant that occurs wherever the crop is cultivated worldwide (Crous and Braun 2003; Kadidia et al. 2018). In several areas of the world, yield losses up to $50 \%$ have been reported (Ouedraogo et al. 1994), and market quality is affected.

The casual agent of the disease is a cercosporoid fungus. Cladosporium personatum, Cercospora arachidis, Cercospora personata, Cercosporidium personatum, Cercosporiopsis personata, Passalora personata, are different names given to the pathogen by different mycologists (Crous and Braun 2003; Videira et al. 2017).

Precise diagnosis and identification of plant pathogens is a pre-requisite for disease management. Recently Videira et al. (2017) performed an inclusive multigene phylogenetic analysis (LSU, ITS and $r p b 2$ ) and clarified the phylogenetic position of genera in the Mycosphaerellaceae including cercosporoid genera. They also studied two isolates causing leaf spot on peanut from USA and Australia (including the type specimen), and their results revealed that the causal agent does not group in Passalora or other above-mentioned genera,

Mounes Bakhshi

mounesbakhshi@gmail.com

1 Department of Botany, Iranian Research Institute of Plant Protection, Agricultural Research, Education and Extension Organization (AREEO), P.O. Box 19395-1454, Tehran, Iran instead they clustered in the new genus Nothopassalora. Therefore, this study (Videira et al. 2017) along with other molecular studies on cercosporoid fungi (Crous et al. 2013; Groenewald et al. 2013; Bakhshi et al. 2014, 2015, 2018) have revealed that the identification of the taxa in this group should strongly rely on the availability of DNA sequence data. On the other hand, molecular data (Crous et al. 2013; Groenewald et al. 2013; Bakhshi et al. 2014, 2018; Bakhshi 2019) demonstrated that species identified on the basis of host, symptomatology and general morphology within different geographic regions, often reside in different phylogenetic clades, indicating that application of names to taxa from different geographic regions, is not warranted.

In Iran the causal agent of leaf spot of peanut has been reported as Passalora personata, Cercospora personata or Cercosporidium personatum based on morphological data (Ershad 2009; Pirnia et al. 2012) and no living culture is available. Therefore, our objective was to confirm the accurate identity of the cercosporoid fungus associated with leaf spot of Arachis hypogaea through morphological and molecular characterisation in Iran.

Surveys were conducted during August and September of the years 2011 and 2018, from peanut cultivated regions of Guilan province (Iran) and severe leaf spot symptoms were observed. Leaf spots were amphigenous, subcircular to circular, dark brown, velvet, 1-9 $\mathrm{mm}$ in diameter, occasionally with yellow halo (Fig. 1). Single-conidial isolates were obtained from symptomatic fresh peanut leaves following the method described by Bakhshi et al. (2011). Axenic cultures and dried plant specimens are maintained in the culture collection of the 


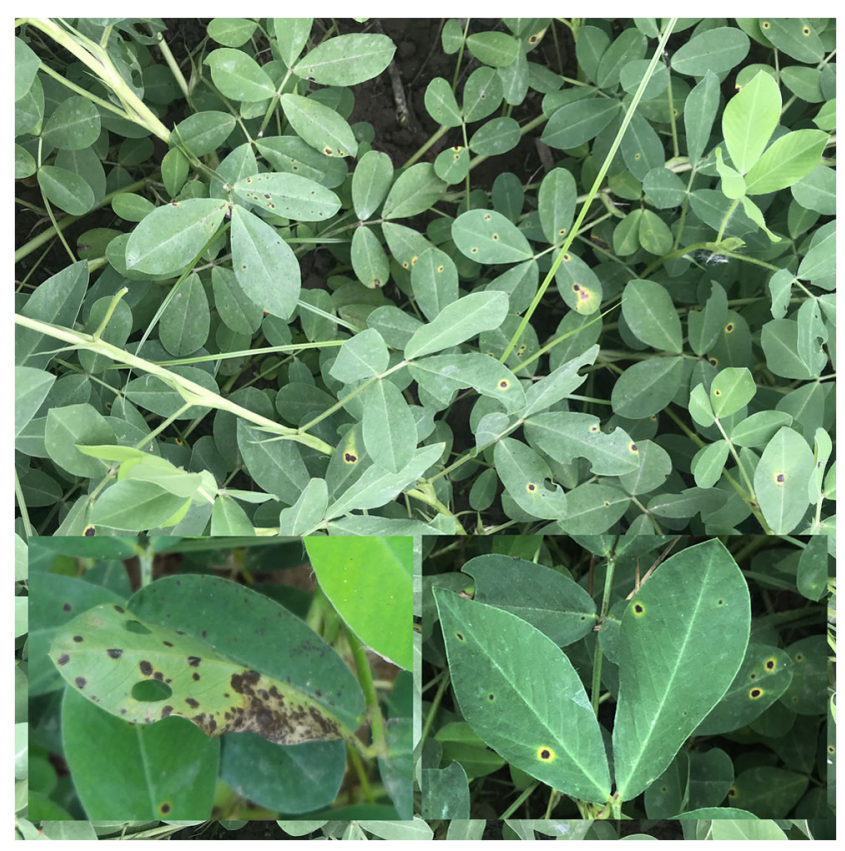

Fig. 1 Peanut leaf spot symptoms caused by Nothopassalora personata

Iranian Research Institute of Plant Protection (IRAN C), and Fungal Herbarium of the Iranian Research Institute of Plant Protection (IRAN F), Tehran, Iran, respectively.

Total genomic DNA was extracted using the protocol of Möller et al. (1992). Parts of the seven loci viz. 28S nrRNA gene (LSU), internal transcribed spacer regions and intervening 5.8S nrRNA gene (ITS) of the nrDNA operon, actin $(a c t A)$, translation elongation factor 1- $\alpha$ (tefl), calmodulin
( $c m d A$ ), histone H3 (his3), and DNA-directed RNA polymerase II second largest subunit (rpb2) were amplified and sequenced. Primers, amplification and sequencing reactions were performed as described by Bakhshi et al. (2014, 2018). Following BLAST searches at the NCBI's GenBank nucleotide database for preliminary identification, a multi-gene tree was constructed using LSU, ITS and $r p b 2$ sequences from taxa within Mycosphaerellaceae (Videira et al. 2017) and Bayesian inference (BI) analyses using MrBayes v. 3.2.6 (Ronquist et al. 2012) as elucidated by Bakhshi et al. (2018). Ramichloridium luteum (CBS 132088) (Dissoconiaceae) was used as the outgroup taxon.

Bayesian analyses of concatenated alignment of the three loci (LSU, ITS and $r p b 2$ ), showed that the Iranian isolates obtained from peanut formed a highly supported clade with two Nothopassalora personata reference cultures sequenced by Videira et al. 2017 (Fig. 2).

Nothopassalora personata (Berk. \& M.A. Curtis) U. Braun, C. Nakash., Videira \& Crous, Studies in Mycology 87: 333.2017 (Fig. 3).

The fungus had the following morphology: In planta: Caespituli amphigenous, mainly hypophyllous, velvety. Mycelium internal. Stromata well-developed, substomatal, intraepidermal, semi-immersed, brown, 15-35 $\mu \mathrm{m}$ diam. Conidiophores aggregated in loose to moderately dense fascicles, arising from stromata or erumpent through the cuticle, medium brown, unbranched, smooth, 1-6-septate, unbranched, straight to curved or geniculate-sinuous, subcylindrical, $50-65(-80) \times 4.5-5.5(-6.5) \mu \mathrm{m}$. Conidiogenous cells integrated, terminal, medium brown,
Fig. 2 Reconstructed phylogeny of Nothopassalora personata isolates from Arachis hypogea, based on Bayesian analysis of the combined LSU, ITS and $r p b 2$ sequences. The scale bar indicates 0.1 expected changes per site. The tree is rooted with

Ramichloridium luteum (CBS 132088)

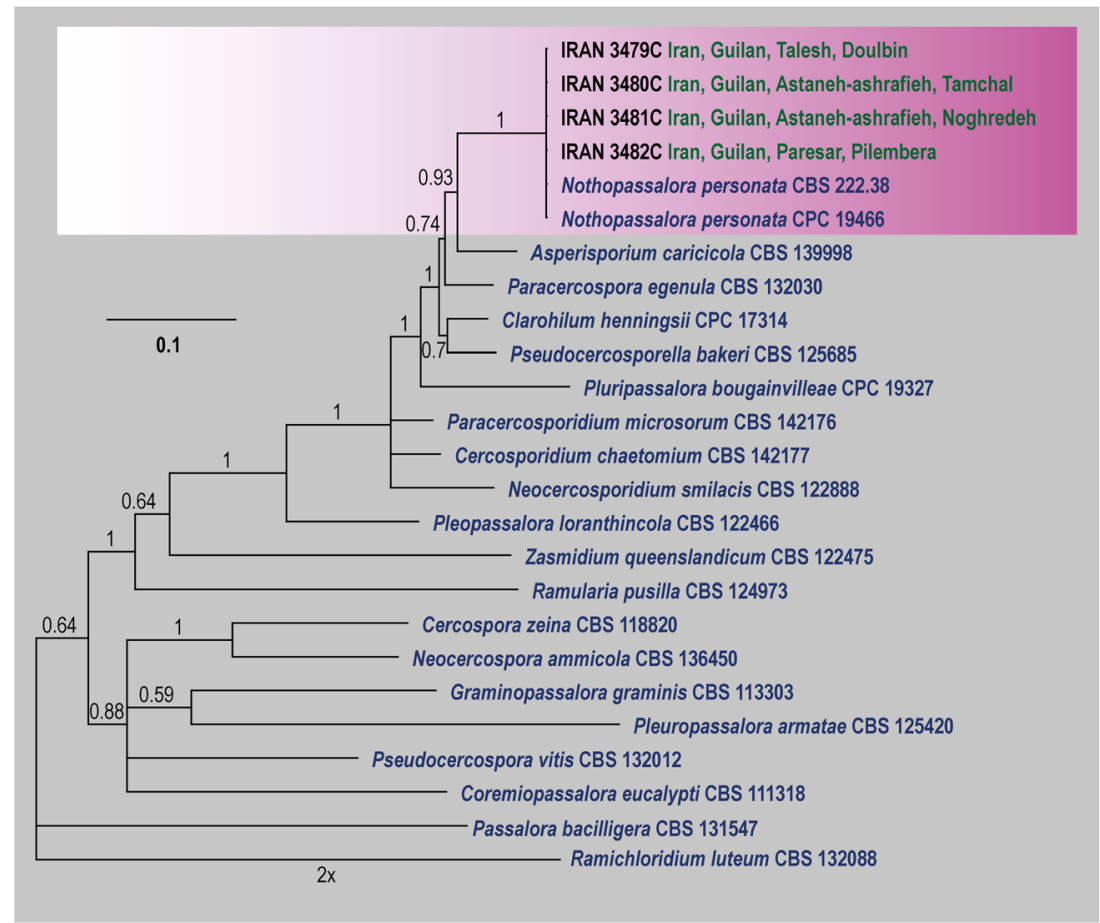



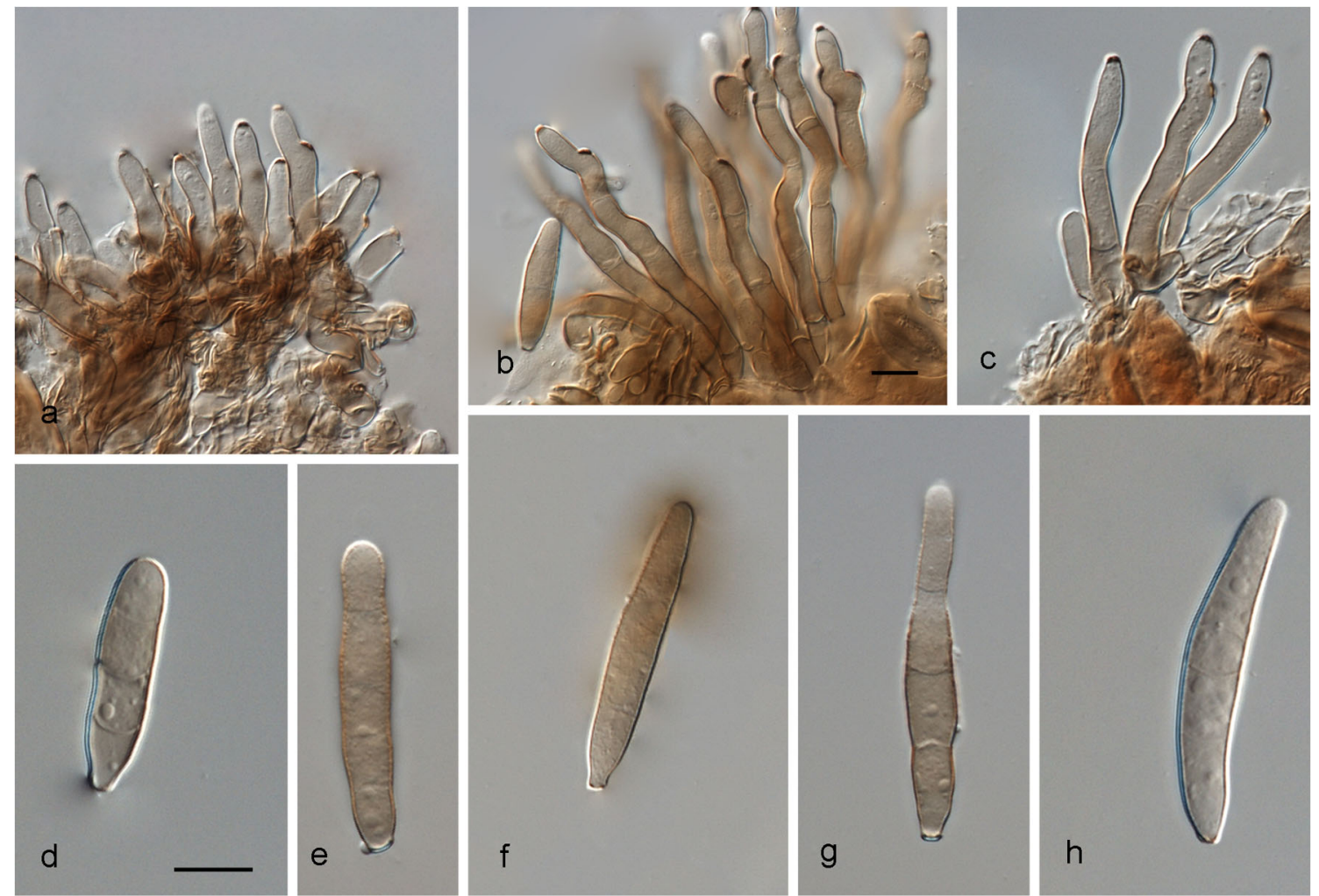

Fig. 3 Morphological characteristics of Nothopassalora personata . $(\mathbf{a}-\mathbf{c})$ Fasciculate conidiophores, $(\mathbf{d}-\mathbf{h})$ conidia. Scale bars $=10 \mu \mathrm{m}$

polyblastic, proliferating sympodially, with conspicuous conidiogenous loci thickened, darkened and refractive, 1.5$3 \mu \mathrm{m}$ diam. Conidia solitary, pale brown, subcylindrical to obclavate, straight to slightly curved, apex obtuse to rounded, base truncate to obconically truncate, $1-3(-7)$-septate, $(15-) 39-50(-70) \times(5-) 7-8 \mu \mathrm{m}$; hila thickened, darkened and refractive, $1.5-3.5 \mu \mathrm{m}$ diam (Fig. 3).

In culture: Colonies very slow-growing (5-7 $\mathrm{mm}$ diam after 14 days), convex with papillate surface, irregular margins compressing the medium, aerial mycelium velvety, iron grey, dark mouse grey reverse; not sporulating.

Material examined: IRAN. Guilan Province: Astaneh-

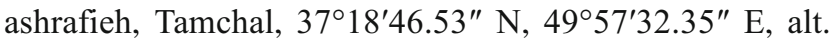
$4 \mathrm{~m}$, on Arachis hypogaea (Fabaceae), 15 August 2018, M. Bakhshi (IRAN 17624F, IRAN 3480C = P 721) $(\mathrm{LSU}=$ MN422340; ITS = MN422348; $r p b 2=$ MN422344). Guilan Province: Astaneh-ashrafieh, Noghredeh, $37^{\circ} 21^{\prime} 40.26^{\prime \prime} \mathrm{N}$, 49 56'27.88" E, alt. 4 m, on Arachis hypogaea, 15 August 2018, M. Bakhshi (IRAN 17625F, IRAN 3481C = P 722) $(\mathrm{LSU}=\mathrm{MN} 422341 ; \mathrm{ITS}=\mathrm{MN} 422349 ; r p b 2=\mathrm{MN} 422345)$. Guilan Province: Talesh, Doulbin, on Arachis hypogaea, 17 September 2011, M. Bakhshi (IRAN 17626F, IRAN 3479C = P 23) $(\mathrm{LSU}=\mathrm{MN} 422339 ;$ ITS $=\mathrm{MN} 422347 ; r p b 2=$ MN422343; $a c t A=\mathrm{MN} 422357 ;$ tef $1=\mathrm{MN} 422374 ; \mathrm{cmd} A=$ MN422408; his3 = MN422391). Guilan Province: Paresar, Pilembera, $37^{\circ} 35^{\prime} 43.51^{\prime \prime} \mathrm{N}, 4^{\circ} 04^{\prime} 51.62^{\prime \prime} \mathrm{E}$, on Arachis hypogaea, 17 August 2018, M. Bakhshi (IRAN 17627F,
IRAN $3482 \mathrm{C}=\mathrm{P} 723)(\mathrm{LSU}=\mathrm{MN} 422342 ; \mathrm{ITS}=$ $\mathrm{MN} 422350 ; r p b 2=\mathrm{MN} 422346)$.

In this study, $N$. personata was confirmed as the cercosporoid fungus causing leaf spot of peanut in Iran. To our knowledge this is the first molecular confirmation of $N$. personata in Asia. Furthermore, first sequences of the actA, tef1, cmdA and his 3 loci have also been generated for this species.

Acknowledgments The Iran National Science Foundation (INSF) and the Research Deputy of the Iranian Research Institute of Plant Protection, Agricultural Research, Education and Extension Organization (AREEO), Tehran, Iran are acknowledged for financial support.

\section{References}

Bakhshi M, Arzanlou M, Babai-Ahari A (2011) Uneven distribution of mating type alleles in Iranian populations of Cercospora beticola, the causal agent of Cercospora leaf spot disease of sugar beet. Phytopathol Mediterr 50:101-109

Bakhshi M, Arzanlou M, Babai-Ahari A, Groenewald JZ, Crous PW (2014) Multi-gene analysis of Pseudocercospora spp. from Iran. Phytotaxa 184:245-264

Bakhshi M, Arzanlou M, Babai-ahari A, Groenewald JZ, Crous PW (2018) Novel primers improve species delimitation in Cercospora. IMA Fungus 9:299-332 
Bakhshi M (2019) Epitypification of Cercospora rautensis, the causal agent of leaf spot disease on Securigera varia, and its first report from Iran. FUSE 3:157-163

Crous PW, Braun U (2003) Mycosphaerella and its anamorphs: 1. Names published in Cercospora and Passalora. CBS Biodiversity Series 1: $1-571$

Crous PW, Braun U, Hunter GC, Wingfield MJ, Verkley GJM, Shin HD, Nakashima C, Groenewald JZ (2013) Phylogenetic lineages in Pseudocercospora. Stud Mycol 75:37-114

Ershad D (2009). Fungi of Iran. Ministry of Jihad-e-Agriculture. Agricultural Research, Education and Extension Organization, Tehran, Iran

Groenewald JZ, Nakashima C, Nishikawa J, Shin HD, Park JH, Jama AN, Groenewald M, Braun U, Crous PW (2013) Species concepts in Cercospora: spotting the weeds among the roses. Stud Mycol 75: $115-170$

Kadidia K, Kouka SH, Abel NT, Bawomon N (2018) Integrated management of leaf spot of peanut with aqueous leaf extract of Lippia multiflora Moldenke and Chlorothalonil. Int J Appl Microbiol Biotechnol Res 6:8-14

Möller E, Bahnweg G, Sandermann H, Geiger H (1992) A simple and efficient protocol for isolation of high molecular weight DNA from filamentous fungi, fruit bodies, and infected plant tissues. Nucleic Acids Res 20:6115-6116

Ouedraogo M, Smith OD, Simpson CE, Smith DH (1994) Early and late leaf spot resistance and agronomic performance of nineteen interspecific derived peanut lines. Peanut Sci 21:99-104

Pirnia M, Zare R, Zamanizadeh HR, Khodaparast A (2012) New records of cercosporoid hyphomycetes from Iran. Mycotaxon 120:157-169

Ronquist F, Teslenko M, van der Mark P, Ayres DL, Darling A, Höhna S, Larget B, Liu L, Suchard MA, Huelsenbeck JP (2012) MrBayes 3.2: eficient Bayesian phylogenetc inference and model choice across a large model space. Syst Biol 61:539-542

Videira SIR, Groenewald JZ, Nakashima C, Braun U, Barreto RW, de Wit PJGM, Crous PW (2017) Mycosphaerellaceae - Chaos or clarity? Stud Mycol 87:257-421 